\title{
A Study to Investigate State of Ethical Development in E-Learning
}

\author{
AbdulHafeez Muhammad ${ }^{1,2}$ \\ ${ }^{1}$ College of Computer Science, \\ King Khalid University, Abha - \\ Saudi Arabia \\ ${ }^{2}$ Kulliya of ICT, IIUM, Kuala \\ Lumpur, Malaysia
}

\author{
Quadri N Naveed ${ }^{1,2}$
${ }^{1}$ College of Computer Science,
King Khalid University, Abha - Saudi Arabia
${ }^{2}$ Kulliya of ICT, IIUM, Kuala Lumpur, Malaysia \\ Quadri N Naveed ${ }^{1,2}$
${ }^{1}$ College of Computer Science,
King Khalid University, Abha - Saudi Arabia
${ }^{2}$ Kulliya of ICT, IIUM, Kuala Lumpur, Malaysia \\ Quadri N Naveed ${ }^{1,2}$
${ }^{1}$ College of Computer Science,
King Khalid University, Abha - Saudi Arabia
${ }^{2}$ Kulliya of ICT, IIUM, Kuala Lumpur, Malaysia \\ Quadri N Naveed ${ }^{1,2}$
${ }^{1}$ College of Computer Science,
King Khalid University, Abha - Saudi Arabia
${ }^{2}$ Kulliya of ICT, IIUM, Kuala Lumpur, Malaysia
}

\author{
Mohd. Feham MD. Ghalib \\ Kulliya of Islamic Revealed \\ Knowledge and Human Sciences, \\ International Islamic University, \\ Kuala Lumpur, Malaysia
}

\author{
Farooq Ahmad \\ College of Computer Science \& \\ Information Technology, \\ University of AlBaha, \\ Al Baha, Kingdom of Saudi Arabia
}

Abstract-Different researches evidenced that e-learning has provided more opportunities to behave unethically than in traditional learning. A descriptive quantitative enquiry-based study is performed to explore same issue in e-Learning environments. The factors required for ethical development of students were extracted from literature. Later, efforts are made to assess their significance and their status in e-Learning with 5point Likert scale survey. The sample consisted of 47 teachers, 298 students, and 31 administrative staff of e-learning management being involved in e-Learning. The work also observed state of students on various ethical behaviors. The study emphasized that the physical presence of teacher, an ethically conducive institutional environment, and the involvement of the society members are among the main factors that help in the ethical development of a student which are missing in eLearning. The results of the study showed that the moral behavior of e-Learners is at decline because of lack of these required factors in e-Learning. This work also suggested the need of a model indicating how these deficiencies can be addressed by the educational institutions for ethical development of higher education learners.

\section{Keywords-e-Learning; ethical development; ethics}

\section{INTRODUCTION}

The objective of education is not only to make a student knowledgeable but also add rational thinking self-sufficiency, knowledge ability, and to ethically develop a student [1]. Moreover, it is the responsibility of university education to produce graduates who use their competence for the welfare of the society. The written codes of ethics and making it binding on the members to follow for almost all the professional bodies (IEEE, ACM, Medical and others) is an indication of the necessity of ethical understanding [2]. Many studies show that ethical understanding and its application are declining in graduates [3]-[6] which is creating harmful situations for the society. There are many reasons for the gradual decline in the ethical development of graduates [6][9]. Some of them are attention to child at the early age in the family [10]-[12], disintegrating family systems [3], [12], no

\author{
Asadullah Shah \\ Kulliya of ICT, \\ International Islamic University Malaysia \\ Kuala Lumpur, Malaysia
}

attention to ethical development in early education [8], [13], the philosophy that knowledge should be independent of religion and local social context [14]-[16], disappearance of explicit contents on ethics from the study material [3], [17], and the quick fix approach and economic push to teach market-oriented courses [3], [18].

This study is part of a bigger project to explore these ethical issues in e-Learning by highlighting the need of a model which supports in moral and ethical development of students. In the remaining part of the paper, statement of problem, objective of study, and literature review would be discussed first. Later, data analysis and its interpretation would be described. Finally, conclusion and future work would be highlighted.

\section{STATEMENT OF PROBLEM}

Despite the many advantages of integrating technologies in education in the form of e-Learning, it has exacerbated the problems of cheating, plagiarism, procrastination, and violation of privacy [19]. Moreover temptation for unethical behavior among students is higher in e-Learning as compared with traditional learning, so the chances for learners to deviate from their academic objectives and behave unethically are higher in e-Learning[6], [7], [10], [20]-[22]. Many researchers have pointed out that although the ethical development of graduates and professionals in general is at decline, the situation is more alarming in case of e-Learning [4], [6], [7], [17], [19], [23]-[25]. It has been realized that ethical issues are on the rise in traditional learning, and specifically in the context of e-Learning due to impact of technology on teacher, society, study material, and academic institutions. As a result, both the society and professions are suffering. A similar perception that the ethical behavior of students in e-Learning is weaker as compared to the courses offered through traditional methods existed in King Khalid University of Kingdom of Saudi Arabia. The Ministry of Higher Education of the Kingdom of Saudi Arabia is supporting e-learning because of intrinsic needs of the country. Therefore, it is 
necessary to study and investigate the state of ethical development in e-Learning at Saudi universities and suggests some ways, which can help to reduce the risks of factors involved in encouraging students on unethical behavior.

\section{PURPOSE OF STUDY}

The purpose of this paper is to investigate state of ethical development as perceived by stakeholders by identifying the required factors of ethical development

The study aimed to achieve the following objectives:

a) To assess the significance of the factors required for ethical development of students.

b) To see the status of the factors required for ethical development of students in e-Learning.

c) To observe the status of ethical behavior of students in e-Learning.

\section{LITERATURE REVIEW}

\section{A. E-Learning}

Creation, dissemination, managing data, and storing information are some of the activities performed in academic institution through different information and communication tools called e-Learning [26]. Authors of another study [27] believe that the procedure of acquiring knowledge and skills consists of five main features. These features are the teacher, the content, the learner, goals to be achieved, and the context or learning environment. Various changes have taken place in the contemporary world through advancements in information and communication technologies (ICTs). Elements of elearning have also been revolutionized through the use of ICTs. Delivery of study material, evaluation of the abilities of students and improvement of students through teacher and student interaction is done through the use of ICTs in elearning institutions. Most of the academic institutions are using e-learning as educational platform called Learning Management System (LMS) because of its advantages as synchronous and asynchronous learning, greater increase to information, more collaboration, better communication and lastly, improvement in pedagogical cost-effectiveness [28]. Blended and fully online modes are the two modes of elearning used in academic institutions. The mode, in which entire contents are delivered through technology without using learner's physical interaction with the instructor, is the fully online mode. On the other hand, a combination of face-to-face and virtual environment in a traditional classroom is known as blended mode. One of the basic differences between a learning classroom and a traditional classroom is that it is not required by the students and instructors to be always physically present together in an e-learning classroom.

\section{B. E-Learning in Kingdom of Saudi Arabia (KSA)}

E-Learning has received much attention amongst the education sector and academic communities of Saudi Arabia as it offers access to many students who aspire to study at the universities but live in remote areas. In the case of female students, parents do not allow them to travel to cities for education. Ministry of Higher Education became more interested in integrating e-Learning in universities, opening new avenues of delivering instruction, making learning accessible and most importantly, improving students learning outcomes[29], [30].

The Ministry of Higher Education, aiming to facilitate the electronic environment and provisions for their universities, has established the National Centre for e-Learning and Distance Education (NCeL). Recently, almost all Saudi universities have integrated e-Learning in their degree program by choice and demand of county. King Khalid University (KKU), Abha, is one of the largest universities in KSA having more than 50,000 students and offering blended and online courses along with the traditional offerings in various disciplines [31]. The KKU is amongst the first higher education institutes in Saudi Arabia that employs technology in educating students. KKU has observed three stages of elearning since 2009, which are: supplementary level, blended level, and entirely online level[31].

\section{Ethical Development}

Ethics can be defined as socially acceptable and moral behavior, which is contradictory with wrong doings or taboos of the society [32]. The term "ethics" is often used to describe the scientific study of moral behavior. Character, Morals, Values, and Ethics are the concepts of sociology which are interrelated with each other for ethical development [33]. There is a particular set of values, beliefs, and means through which, objectives and aims of educational institutions are delivered. These customs, attitudes and understandings are necessary to be understood by adults and youth. Through this, students are able to build their characters by learning selfcompetence, awareness, rational thinking and at like literate people in the society [34]. The main purpose of education is to give a direction for a successful life. The new generation is supported through the implementation of essential skills, knowledge, attitudes and understandings to make their personality and intellect useful for the welfare of the society. A teacher plays a significant role in this process because he/she grooms the already existing talents according to the requirement in every individual [35], [36].

\section{Ethical Issue in e-Learning causing unethical behavior}

Recent advancement of technologies has effected on the structure of academic institutes, family and societies which become the major reason for the deficiencies in the moral character of individual. There is an objection on ICT-based education that it is focusing only on advanced styles and methods of education but not caring for betterment and advancement of society [37], [38]. Other than this, even supporters of e-Learning accept that it is not offering social and extracurricular support which are important for instilling cultural and moral values[9], [39], [40]. Ethical issues have become more dominant due to the use of technology. In order to fight this challenge, UN and UNESCO started special "Ethics Education Program". A declaration was also put forward by the European Association and European universities so that a conference can be arranged to continue the progress of ethical development in higher education. Almost all the professional bodies in the world have developed their Code of Ethics, which indicates that there has been a violation of ethical codes in the past or present [41]. 
In his study [42] highlighted that data collection, security, privacy, trust, and ever-present technologies are some of the ethical issues, which have been a consequence of latest technologies. This has also given rise to less human contact due to which, human beings have become more technologydependent.

There are six critical ethical issues, which are - access of intellectual property, privacy, protecting children, and securing information that occur due the use of electronic mean[43].

Due to the integration of technologies, academic institutions are facing direct or indirect ethical issues. In the last decade, students have become more ethically declined even after academic learning and education.

According to Brown [10], academic frauds and other kinds of electronic problems are faced by educational institutions through the use of technology and internet.

Different researchers also highlighted some of the other ethical issues in the educational world [44]-[46]. They mentioned that students often use unauthorized resources for the completion of their assignments because copy pasting is the common practice of almost all educational world. In addition, e-learners often work in groups to perform an individual task and they often take advantage of the possible misuse of ICTs.

Moreover, 59\% of the U.S students enrolled in e-Learning programmes have admitted that they have been in some kind of academic fraud in their academic period. About 27\% indicated very frequent involvement while $32 \%$ marked frequent involvement according to The National Survey of Student Engagement [47]. The use of mobile phones in academic institutions has also made students unethical. They usually divert their attention from studies towards playing games on mobile phones so they spend time on luxuries by using them. About $40 \%$ of students affirmed that they have used mobile phones for sending text messages or receiving text messages during a lecture according to a survey report. On the other hand, $70 \%$ of the students stated that their phones rang in the middle of the class. Unethical use of ICTs has promoted plagiarism in academic institutions, suggesting the need for further investigation[48], [49]. Other than these, authors [6]-[8], [25], [26], [50], [51] also highlight ethical issues in e-learning and observed following deficiencies which can become the cause of these issues.

- Lack of direct or face-to-face interactions with students.

- Lack of counseling, which promotes flexible and independent learning environment.

- Lack of involvement in the social circle, which makes students isolated from their families and friends.

\section{METHODS AND PROCEDURES}

The study was descriptive quantitative based on a survey approach. The population of the study was students, teachers and the administrative staff of e-learning management working in e-learning environments of King Khalid
University, Abha. Random sampling technique was use to select 47 teachers, 298 students and 31 administrative staff being involved in e-Learning. A self-developed questionnaire based on literature was developed to explore three area of study, first, to see the significance of the factors required for ethical development of student, second, to observe the status of these important factors in e-Learning environment, and finally to investigate the ethical behavior of students in eLearning. The instrument was also pilot tested and verified through the experts of the field.

\section{DATA ANALYSIS AND INTERPRETATION}

\section{A. Demographic Information}

Quantitative data were collected from 376 students, teachers, and administrative staff of King Khalid University all involved in e-Learning. The data were tabulated and analysed by using SPSS. The respondents belonged to various disciplines and had varying experience with e-learning as shown in table- 1 in table- 2 respectively. In the sample, the number of respondents (376) related to e-Learning were 47 teachers, 298 students, and 31 from staff to manage eLearning and 06 were from other categories of support staff. The respondents were associated with the fields of study in elearning as Computer Science (156), Science (75), Management Science (67), Sharia and Law (62),) and Medical Sciences (16). Among these 376 respondents, 99 were associated with e-Learning for a period of less than one year, 141 for less than three years but more than one year, and 136 were associated with e-Learning for more than three years.

TABLE I. CATEGORIES OF RESPONDENT W.R.T. THEIR DisCIPLINES

\begin{tabular}{|c|c|c|c|c|c|c|}
\hline 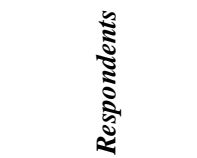 & 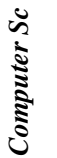 & 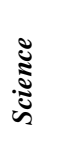 & 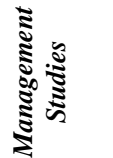 & ज्ञ & 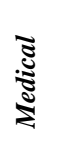 & $\underset{\Xi}{\Xi}$ \\
\hline Teachers & 21 & 10 & 4 & 7 & 5 & 47 \\
\hline e-Learning Staff & 14 & 6 & 6 & 2 & 3 & 31 \\
\hline Students & 121 & 59 & 57 & 53 & 8 & 298 \\
\hline Total & 156 & 75 & 67 & 62 & 16 & 376 \\
\hline
\end{tabular}

TABLE II. CATEGORIES OF RESPONDENT W.R.T EXPERIENCE IN THE USE OF E- LEARNING

\begin{tabular}{|c|c|c|c|c|}
\hline 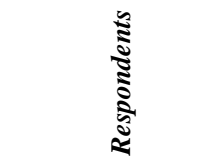 & $\begin{array}{l}\bar{\Xi} \\
\vdots \\
\vdots \\
\vdots \\
\vdots \\
\vdots \\
\vdots\end{array}$ & 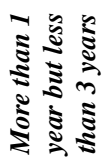 & $\begin{array}{l}3 \\
\vdots \\
\vdots \\
\vdots \\
\vdots \\
\vdots\end{array}$ & $\stackrel{\Xi}{\Xi}$ \\
\hline Teachers & 11 & 23 & 13 & 47 \\
\hline e-Learning Staff & 8 & 3 & 20 & 31 \\
\hline Students & 80 & 115 & 103 & 298 \\
\hline Total & 99 & 141 & 136 & 376 \\
\hline
\end{tabular}

The descriptive and inferential statistics were applied for data analysis to find significance of factors and their status in e-learning.

\section{B. Significance of Factors Required for Ethical Development}

The literature indicated that the main factors for ethical development are the teacher, members of society (including 
parents, family and friends), physical environment provided to students, and explicit course contents on ethics. The statements mentioned in Table 3 were asked to the respondents to assess the significance of factors required for ethical development.

TABLE III. SIGNIFICANCE OF THE FACTORS REQUIRED FOR ETHICAL DEVELOPMENT OF STUDENTS ( $\mathrm{N}=376)$

\begin{tabular}{|l|c|c|c|c|}
\hline Statements & Min. & Max. & Mean & $\begin{array}{c}\text { Std. } \\
\text { Deviation }\end{array}$ \\
\hline $\begin{array}{l}\text { Physical presence of teacher plays } \\
\text { significant role in the ethical } \\
\text { development of the students. }\end{array}$ & 1 & 5 & 4.29 & 0.732 \\
\hline $\begin{array}{l}\text { Members of society play a significance } \\
\text { role in the ethical development of } \\
\text { students. }\end{array}$ & 1 & 5 & 4.15 & 0.928 \\
\hline $\begin{array}{l}\text { Physical environment provided to } \\
\text { student plays a significant role in the } \\
\text { ethical development of students. }\end{array}$ & 1 & 5 & 4.14 & 0.842 \\
\hline $\begin{array}{l}\text { Study material in the curriculum plays a } \\
\text { major role in the ethical development of } \\
\text { students }\end{array}$ & 1 & 5 & 3.53 & 1.070 \\
\hline
\end{tabular}

Strongly agree $=5$, Agree $=4$, Neutral $=3$, Disagree $=2$, Strongly disagree $=1$

Table 3 indicates that most of the respondents strongly agree about the significance of factors required for ethical development of students i.e., physical presence of teacher $($ Mean $=4.29$, Std. Deviation=0.732), member of society (Mean $=4.15$, Std. Deviation $=0.928)$, physical environment provided to student $($ Mean= 4.14, Std. Deviation=0.842) and Study material in curriculum (Mean= 3.53, Std. Deviation=1.070). All respondents agreed that these factors play a significant role in ethical development of students.

It can be concluded from the data in Table 3 that among all the respondents, factor, "physical presence of teacher" is having the highest mean value (4.29). Therefore, it is the most significant factor and study material in curriculum having least mean value (3.53) is the least significant factor for the ethical development of students.

Analysis of variance (ANOVA) test was applied to compare the opinion of teachers, students and e-learning management staff about significance of the factors required for ethical development of students. Significant level of $\mathrm{p}<$ 0.05 was adopted for the study. It can be seen in Table 4 , that there is no significant difference among the opinion of teachers, students and e-learning management staff about different factors for ethical development of students. It can be concluded that all the respondents have the same opinion regarding the factors for ethical development of students.

TABLE IV. COMPARISON OF OPINION OF TEACHERS, STUDENTS AND ELEARNING MANAGEMENT STAFF ON SIGNIFICANCE OF THE FACTORS REQUIRED FOR ETHICAL DEVELOPMENT OF STUDENTS (N=375)

\begin{tabular}{|l|l|l|l|l|l|l|}
\hline Variables & $\begin{array}{l}\text { Sum of } \\
\text { Squares }\end{array}$ & Df & $\begin{array}{l}\text { Mean } \\
\text { Square }\end{array}$ & F & Sig. \\
\hline \multirow{2}{*}{$\begin{array}{l}\text { Physical presence } \\
\text { of teacher }\end{array}$} & $\begin{array}{l}\text { Between } \\
\text { Groups }\end{array}$ & 2.414 & 2 & 1.207 & & \\
\cline { 2 - 5 } & $\begin{array}{l}\text { Within } \\
\text { Groups }\end{array}$ & 198.565 & 373 & 0.532 & 2.267 & 0.105 \\
\cline { 2 - 5 } & Total & 200.979 & 375 & & & 0.692 \\
\hline Members of society & $\begin{array}{l}\text { Between } \\
\text { Groups }\end{array}$ & 0.637 & 2 & 0.318 & 0.368 & 0.60 \\
\hline
\end{tabular}

\begin{tabular}{|c|c|c|c|c|c|c|}
\hline & $\begin{array}{l}\text { Within } \\
\text { Groups }\end{array}$ & 322.416 & 373 & 0.864 & & \\
\hline & Total & 3232.053 & 375 & & & \\
\hline \multirow{3}{*}{$\begin{array}{l}\text { Physical } \\
\text { environment }\end{array}$} & $\begin{array}{l}\text { Between } \\
\text { Groups }\end{array}$ & 0.697 & 2 & 0.349 & \multirow{3}{*}{0.490} & \multirow{3}{*}{0.613} \\
\hline & $\begin{array}{l}\text { Within } \\
\text { Groups }\end{array}$ & 265.385 & 373 & 0.711 & & \\
\hline & Total & 266.082 & 375 & & & \\
\hline \multirow{3}{*}{ Study material } & $\begin{array}{l}\text { Between } \\
\text { Groups }\end{array}$ & 3.467 & 2 & 1.734 & \multirow{3}{*}{1.517} & \multirow{3}{*}{0.221} \\
\hline & $\begin{array}{l}\text { Within } \\
\text { Groups }\end{array}$ & 426.150 & 373 & 1.142 & & \\
\hline & Total & 429.617 & 375 & & & \\
\hline
\end{tabular}

\section{Status of Factors Required for Ethical Development}

Here, an effort is made to observe the status of factors, essential for ethical development in e-Learning environments. The statements related to same factors were asked to respondents to see the status of these factors in e-Learning environment as stated in Table 5.

TABLE V. STATUS OF THE FACTORS REQUIRED FOR ETHICAL DEVELOPMENT OF STUDENTS IN E-LEARNIN (N=376)

\begin{tabular}{|l|l|l|l|l|}
\hline Statements & Min. & Max. & Mean & $\begin{array}{l}\text { Std. } \\
\text { Deviation }\end{array}$ \\
\hline $\begin{array}{l}\text { There is lack of physical presence of } \\
\text { teacher in e-Learning, which is affecting } \\
\text { ethical development of student. }\end{array}$ & 1 & 5 & 4.03 & 0.861 \\
\hline $\begin{array}{l}\text { Independent and flexible learning } \\
\text { environment provided for e-Learning is } \\
\text { not appropriate for the ethical } \\
\text { development. }\end{array}$ & 1 & 5 & 3.95 & 1.180 \\
\hline $\begin{array}{l}\text { There is lack of involvement of } \\
\text { members of the society in e-Learning, } \\
\text { which is affecting ethical development. }\end{array}$ & 1 & 5 & 4.14 & 0.796 \\
\hline $\begin{array}{l}\text { There is lack of ethical contents in study } \\
\text { material in e-Learning, which is } \\
\text { negatively affecting the students. }\end{array}$ & 1 & 5 & 3.94 & 1.063 \\
\hline
\end{tabular}

Strongly agree $=5$, Agree $=4$, Neutral $=3$, Disagree $=2$, Strongly disagree $=1$

Table 5 shows the opinion of respondents about the status of factors required for ethical development of students. In the opinion of all respondents, the factors, that is," "lack of physical presence of teacher in e-learning" (Mean=4.03, Std. Deviation=0.861), "independent and flexible learning environment" (Mean=3.95, Std. Deviation= 1.180), "lack of involvement of members of society" (Mean= 4.14, Std. Deviation=0.796), "lack of ethical contents in study material" (Mean= 3.94, Std. Deviation=1.063), are affecting negatively in e-learning environment for ethical development of students. The conclusion that can be drawn is that "lack of involvement of society member in e-learning" having highest mean value (4.14) is the most deficient factor, which can influence more for ethical development of students. While "lack of ethical contents in study materials in e-learning" having mean value (3.94) is the least affecting factor for ethical development of students.

TABLE VI. COMPARISON OF OPINION OF TEACHERS, STUDENTS AND ELEARNING MANAGEMENT STAFF ABOUT THE STATUS OF THE FACTORS REQUIRED FOR ETHICAL DEVELOPMENT OF STUDENTS ( $\mathrm{N}=375$ )

\begin{tabular}{|l|l|l|l|l|l|l|}
\hline Variables & $\begin{array}{l}\text { Sum of } \\
\text { Squares }\end{array}$ & df & $\begin{array}{l}\text { Mean } \\
\text { Square }\end{array}$ & F & Sig. \\
\hline $\begin{array}{l}\text { lack of physical } \\
\text { presence of teacher }\end{array}$ & $\begin{array}{l}\text { Between } \\
\text { Groups }\end{array}$ & 2.182 & 2 & 1.091 & 1.477 & 0.230 \\
\hline
\end{tabular}




\begin{tabular}{|c|c|c|c|c|c|c|}
\hline \multirow[t]{2}{*}{ in e-Learning } & $\begin{array}{l}\text { Within } \\
\text { Groups }\end{array}$ & 275.552 & 373 & 0.739 & & \\
\hline & Total & 277.734 & 375 & & & \\
\hline \multirow{3}{*}{$\begin{array}{l}\text { Independent and } \\
\text { flexible learning } \\
\text { environment }\end{array}$} & $\begin{array}{l}\text { Between } \\
\text { Groups }\end{array}$ & 4.043 & 2 & 2.021 & \multirow{3}{*}{1.456} & \multirow{3}{*}{0.235} \\
\hline & $\begin{array}{l}\text { Within } \\
\text { Groups }\end{array}$ & 517.997 & 373 & 1.389 & & \\
\hline & Total & 522.050 & 375 & & & \\
\hline \multirow{3}{*}{$\begin{array}{l}\text { lack of involvement } \\
\text { of members of the }\end{array}$} & $\begin{array}{l}\text { Between } \\
\text { Groups }\end{array}$ & 0.261 & 2 & 0.130 & \multirow{3}{*}{0.205} & \multirow{3}{*}{0.815} \\
\hline & $\begin{array}{l}\text { Within } \\
\text { Groups }\end{array}$ & 237.269 & 373 & 0.636 & & \\
\hline & Total & 237.529 & 375 & & & \\
\hline \multirow{3}{*}{$\begin{array}{l}\text { Lack of ethical } \\
\text { contents in study } \\
\text { material. }\end{array}$} & $\begin{array}{l}\text { Between } \\
\text { Groups }\end{array}$ & 1.737 & 2 & 0.869 & \multirow{3}{*}{0.768} & \multirow{3}{*}{0.465} \\
\hline & $\begin{array}{l}\text { Within } \\
\text { Groups }\end{array}$ & 422.090 & 373 & 1.132 & & \\
\hline & Total & 423.827 & 375 & & & \\
\hline
\end{tabular}

ANOVA results in Table 6 show that there is no significant difference among the opinion of teachers, students and e-learning management staff about status of factors for ethical development of students in e-learning system. It can be concluded that all the respondents have same opinion regarding the status of factors for ethical development of students in e-learning system.

\section{Status of Ethical Behavior of Students in e-learning courses}

To observe the ethical status of students, only three values that is, plagiarism, punctuality (attendance/attention) and miscommunication (false representation/telling lies) are taken. Many researchers [52], [53] have taken these as the general indicators of unethical behavior of e-learners. Table 7 shows the ethical behavior of students in e-learning by asking statements of three values. The participants were asked to compare the status of the students' behavior for these values as in their conduct in online courses as compared to the normal courses.

TABLE VII. The Status of Ethical Behavior of Students IN ELEARNING (N=376)

\begin{tabular}{|l|l|l|l|l|}
\hline Statements & Min. & Max. & Mean & $\begin{array}{l}\text { Std. } \\
\text { Deviation }\end{array}$ \\
\hline $\begin{array}{l}\text { Plagiarism, copy/paste and cheating are } \\
\text { common among students in e-Learning. }\end{array}$ & 1 & 5 & 4.37 & 0.704 \\
\hline Students are not attentive in e-Learning & 1 & 5 & 3.72 & 1.062 \\
\hline $\begin{array}{l}\text { Students miscommunicate while with } \\
\text { the teachers and other students in e- } \\
\text { Learning }\end{array}$ & 1 & 5 & 3.63 & 1.145 \\
\hline
\end{tabular}

Strongly agree $=5$, Agree $=4$, Neutral $=3$, Disagree $=2$, Strongly disagree $=1$

The values in Table 7 show that Plagiarism, copy/paste and cheating are common among students (Mean= 4.37, Std. Deviation=0.704), Students are not attentive (Mean= 3.72, Std. Deviation=1.062), and students miscommunicate with the teachers and other students (Mean= 3.63, Std. Deviation=1.145). It can be seen that in the opinion of the respondents, in online courses most of the students behave unethically because of more opportunities for cheating and being less serious.
TABLE VIII. COMPARISON OF OPINION OF TEACHERS, STUDENTS AND ELEARNING MANAGEMENT STAFF ABOUT THE STATUS OF ETHICAL DEVELOPMENT OF STUDENTS ( $\mathrm{N}=376$ )

\begin{tabular}{|c|c|c|c|c|c|c|}
\hline \multicolumn{2}{|l|}{ Variables } & $\begin{array}{l}\text { Sum of } \\
\text { Squares }\end{array}$ & df & $\begin{array}{l}\text { Mean } \\
\text { Square }\end{array}$ & $\mathbf{F}$ & Sig. \\
\hline \multirow{3}{*}{$\begin{array}{l}\text { plagiarism, copy/paste } \\
\text { and cheating }\end{array}$} & $\begin{array}{l}\text { Between } \\
\text { Groups }\end{array}$ & 0.850 & 2 & 0.425 & \multirow{3}{*}{0.85} & \multirow{3}{*}{0.42} \\
\hline & $\begin{array}{l}\text { Within } \\
\text { Groups }\end{array}$ & 184.765 & 373 & 0.495 & & \\
\hline & Total & 185.614 & 375 & & & \\
\hline \multirow{3}{*}{ Attention of students } & $\begin{array}{l}\text { Between } \\
\text { Groups }\end{array}$ & 1.034 & 2 & 0.517 & \multirow{3}{*}{0.45} & \multirow{3}{*}{0.63} \\
\hline & $\begin{array}{l}\text { Within } \\
\text { Groups }\end{array}$ & 421.5106 & 373 & 1.130 & & \\
\hline & Total & 422.551 & 375 & & & \\
\hline \multirow{3}{*}{ Miscommunication } & $\begin{array}{l}\text { Between } \\
\text { Groups }\end{array}$ & 1.592 & 2 & 0.796 & \multirow{3}{*}{0.60} & \multirow{3}{*}{0.54} \\
\hline & $\begin{array}{l}\text { Within } \\
\text { Groups }\end{array}$ & 490.022 & 373 & 1.314 & & \\
\hline & Total & 491.614 & 375 & & & \\
\hline
\end{tabular}

ANOVA results in Table 8 show that there is no significant difference among the opinion of teachers, students and e-learning management staff about the three different status of ethical behavior of students in e-learning. Therefore, it can be concluded that all the respondents have same opinion regarding the status of ethical behavior of students in eLearning.

\section{CONCLUSION RECOMMENDATIONS AND FUTURE WORK}

The study was carried out to investigate the status of ethical behavior of students in an e-Learning environment from a sample of 376 stockholders of an e-Learning environment, that is, students, teachers and administrative staff.

From the findings of this study, it may be concluded that teacher, society members (family and friends etc.), environment and policies of academic institution, and teaching of explicit content on ethics are the essential factors for the ethical development of students. It was also tested statistically that, there is no difference among the opinions of respondents about the importance of factors required for ethical development. When respondents were enquired about the status of these essential factors in e-Learning environments, they agreed that lack of physical presence of teacher, no involvement of society members (family and friends etc.), no ethically conducive environment and policies of academic institution, and absence of explicit contents on ethics in courses is the cause of ethical decline of the e-learner. It was also tested statistically that, there is no difference among the opinions of respondents about there is lack of these factors required for ethical development in e-learning. Students' ethical behavior was also tested on three values of plagiarism, attendance/attention, and miscommunications/lies. It was seen that all the respondents agreed that the behavior of e-Learners is more unethical. It was also tested statistically that there is no difference among the opinions of respondents about status of ethical behavior of students in e-Learning. 
Following are some recommendations for the institutions offering e-Learning based on the findings of the study.

- Institutions should provide proper alternatives to compensate for the absence of face to face interaction between students and teachers. For example, there must be interactive sessions, virtual class rooms and at least some physical face to face meetings in the start of the course.

- Teachers should adopt multimedia tools available in learning as technology in appropriate way to compensate for the lack of physical presence of teacher.

- There must be focused and supervised learning environment for students where exams should be conducted by proper monitoring tools like Lockdown browsers or Netopt.

- There must be proper polices and guidelines for students and teachers involved in e-learning. These policies should be properly implemented and monitored.

- The curriculum of professional studies should contain content related to the inculcation of ethical values in the students.

- Parents and the community leaders should be involved in the ethical building mechanism for the university students.

Finally, the study strongly recommends and highlights the need of a model for future work that may help the educators to equip the individuals with moral values and life skills. This study can be considered as base for future researchers because of lack of existing literature about this topic in the Arab countries. Authors of the papers are working to find ways and models which can compensate for the deficiencies identified in the ethical development of e-learners.

\section{REFERENCES}

[1] V. Campbell and R. Bond, "Evaluation of a character education curriculum,” Educ. Values. New York Irvingt. Publ., 1982.

[2] G. Wood, "A cross cultural comparison of the contents of codes of ethics: USA, Canada and Australia," J. Bus. Ethics, vol. 25, no. 4, pp. 287-298, 2000.

[3] F. Ahmad, "Computer Science \&amp; Engineering Curricula and Ethical Development," in Teaching and Learning in Computing and Engineering (LaTiCE), 2014 International Conference on, 2014, pp. 220-225.

[4] C. Anitha and T. S. Harsha, "Ethical Perspectives in Open and Distance Education System.," Turkish Online J. Distance Educ., vol. 14, no. 1, pp. 193-201, 2013.

[5] P. Brey, "Ethical issues for the virtual university," Rep. cEVU Proj. (EuroPACE/European Comm. To Appear online www. cevu. org, pp. 125, 2003.

[6] M. AbdulHafeez, Farooq A, and S. Asadullah, "Resolving Ethical Dilemma in Technology Enhanced Education through smart mobile devices," Int. Arab J. e-Technology, vol. 4, no. 1, pp. 25-31, 2015.

[7] A. H. Muhammad, H. A. Wahsheh, A. Shah, and F. Ahmad, "Ethical perspective of learning management system a model to support moral character of online learner," in Information and Communication Technology for The Muslim World (ICT4M), 2014 The 5th International Conference on, 2014, pp. 1-6.
[8] M. Abdulhafeez, A. Farooq, and S. Asadullah, "Integration of ethical perspective in e-education," EDULEARN12 Proc., pp. 3759-3765, 2012.

[9] M. AbdulHafeez, S. Asadullah, M. Rosydi, and a. Farooq, "Inculcating ethical values in the students through e-Learning platform," 2013 5th Int. Conf. Inf. Commun. Technol. Muslim World, pp. 1-6, Mar. 2013.

[10] T. Brown, "Ethics in eLearning," Rev. Educ. do Cogeime, pp. 211-216, 2008.

[11] Su. Couch and S. Dodd, "Doing the Right Thing," J. Fam. Consum. Sci. Sep, vol. 97, p. 3, 2005.

[12] P. K. Rono and A. A. Aboud, "The role of popular participation and community work ethic in rural development: the case of Nandi District, Kenya," J. Soc. Dev. Afr., vol. 18, no. 2, pp. 77-104, 2003.

[13] A. Colby and W. M. Sullivan, "Ethics teaching in undergraduate engineering education,” J. Eng. Educ., vol. 97, no. 3, pp. 327-338, 2008.

[14] M. H. Khamis and M. J. Salleh, "The philosophy and objectives of education in Islam," 2010.

[15] Z. Al Zeera, Wholeness And Holiness In Education An Islamic Perspective. IIIT, 2001.

[16] K. Musbahtiti, M. Ramadan Saady, and A. Muhammad, "Comprehensive e-Learning system based on Islamic principles," in Information and Communication Technology for the Muslim World (ICT4M), 2013 5th International Conference on, 2013, pp. 1-5.

[17] M. Abdulhafeez, A. Farooq, and S. Asadullah, "INNOVATIVE ROLES AND RESPONSIBILITIES OF TEACHERS AND LEARNERS IN ELEARNING," EDULEARN12 Proc., pp. 4121-4127, 2012.

[18] O. C. Ferrell, J. Fraedrich, and others, Business ethics: Ethical decision making \& cases. Cengage Learning, 2014.

[19] J. Trushell, K. Byrne, and R. Simpson, "Cheating behaviours, the Internet and Education undergraduate students," J. Comput. Assist. Learn., vol. 28, no. 2, pp. 136-145, 2012.

[20] M. I. FARISI, "Academic Dishonesty In Distance Higher Education: Challenges And Models For Moral Education In The Digital Era," Turkish Online J. Distance Educ., vol. 14, no. 4, 2013.

[21] A. H. Mohammad, A. Farooq, and S. Asadullah, "Integration of ethical perspective in e-education," no. July, pp. 3759-3765, 2012.

[22] M. E. Brown and L. K. Treviño, "Ethical leadership: A review and future directions," Leadersh. Q., vol. 17, no. 6, pp. 595-616, 2006.

[23] R. G. Ledesma, "Academic dishonesty among undergraduate students in a Korean university," Res. World Econ., vol. 2, no. 2, p. p25, 2011.

[24] M. Nejati, R. Jamali, and M. Nejati, "Students' ethical behavior in Iran," J. Acad. Ethics, vol. 7, no. 4, pp. 277-285, 2009.

[25] A. H. Muhammad and K. T. Musbah, "Improvement Quality of LMS Through Application of Social Networking Sites.," Int. J. Emerg. Technol. Learn., vol. 8, no. 3, p. pp-48, 2013.

[26] A. Hafeez, M. Muhammad, A. Shah, and others, "Integration of ICT in education: an Islamic perspective.," pp. 61-71, 2011.

[27] T. Sepic, I. Pogarčić, and S. Raspor, "eLearning: The influence of ICT on the style of teaching," in MIPRO, 2010 Proceedings of the 33rd International Convention, 2010, pp. 995-1000.

[28] A. Nawaz and G. M. Kundi, "Demographic implications for the userperceptions of e-learning in higher education institutions of NW. FP, PAKISTAN,” Electron. J. Inf. Syst. Dev. Ctries., vol. 41, 2010.

[29] A. Aljabre, "An exploration of distance learning in Saudi Arabian universities: current practices and future possibilities," Int. J. Instr. Technol. Distance Learn., vol. 9, no. 2, pp. 21-28, 2012.

[30] A. Clementking and A. Muhammad, "Technology Based Learning Analysis of CBCS Model at KKU.," Int. J. Emerg. Technol. Learn., vol. 8, no. 3, 2013.

[31] K. K. U. E-Learning Deanship, "KKU," 2016. [Online]. Available: www.elc.kku.edu.sa. [Accessed: 10-Jan-2016].

[32] P. Bowden and V. Smythe, "Theories on teaching \& training in ethics," 2008.

[33] H. Lee, H. Chang, K. Choi, S.-W. Kim, and D. L. Zeidler, "Developing character and values for global citizens: Analysis of pre-service science teachers' moral reasoning on socioscientific issues," Int. J. Sci. Educ., vol. 34, no. 6, pp. 925-953, 2012. 
[34] I. N. George and U. D. Uyanga, "Youth and Moral Values in a Changing Society," IOSR J. Humanit. Soc. Sci., vol. 19, no. 6, pp. 40-44, 2014.

[35] Z. A. Shaikh and S. A. Khoja, "Personal learning environments and university teacher roles explored using Delphi," Australas. J. Educ. Technol., vol. 30, no. 2, 2014.

[36] M. Abdulhafeez, A. Farooq, and S. Asadullah, "Innovative roles and responsibilities of teachers and learnersin E-Learning," EDULEARN12 Proc., pp. 4121-4127, 2012.

[37] P. Brey, "Ethical issues for the virtual university," Rep. cEVU Proj. (EuroPACE/European Comm. To Appear online www. cevu. org, 2003.

[38] P. Brey, "Social and ethical dimensions of computer-mediated education," J. Information, Commun. Ethics Soc., vol. 4, no. 2, pp. 91$101,2006$.

[39] K. K. Ali, R. Salleh, and M. Sabdin, "A study on the level of ethics at a Malaysian private higher learning institution: comparison between foundation and undergraduate technical-based students," Int. J. Basic and, Appl. Stat., vol. 10, no. 8, pp. 35-49, 2010.

[40] J. L. Cordova and P. Thornhill, "Academic honesty and electronic assessment: tools to prevent students from cheating online---tutorial presentation," J. Comput. Sci. Coll., vol. 22, no. 5, pp. 52-54, 2007.

[41] H. Ten Have, "Promoting and applying bioethics: the ethics programme of UNESCO," 2010.

[42] B. C. Stahl, S. Rogerson, and K. J. Wakunuma, "Future Technologies: The Matter of Emergent Ethical Issues in Their Development," in Future Computing, Service Computation, Cognitive, Adaptive, Content, Patterns, 2009. COMPUTATIONWORLD'09. Computation World:, 2009, pp. 603-607.

[43] B. Kracher and C. L. Corritore, "Is there a special e-commerce ethics?," Bus. Ethics Q., pp. 71-94, 2004.

[44] R. A. Fess, "Cheating and plagiarism. Ethics and Higher Education.
May, WW editor.” New York: Macmillan Publishing Company and American Council on Education, 1990.

[45] W. L. Kibler, "Academic Dishonesty: A Student Development Dilemma.," NASPA J., vol. 30, no. 4, pp. 252-267, 1993.

[46] D. L. McCabe, K. D. Butterfield, and L. K. Trevino, "Academic dishonesty in graduate business programs: Prevalence, causes, and proposed action," Acad. Manag. Learn. Educ., vol. 5, no. 3, pp. 294305, 2006.

[47] G. D. Kuh, "The national survey of student engagement: Conceptual and empirical foundations," New Dir. Institutional Res., vol. 2009, no. 141, pp. 5-20, 2009.

[48] T. Andrews, L. Dyson, R. Smyth, and R. Wallace, "The Ethics of MLearning: Classroom Threat or Enhanced Learner Agency?," 2011.

[49] A. Berglund, A. Pears, A. Nylén, F. Ahmad, B. Alghamdi, K. Alghamdi, A. Alhabish, A. Aljoufi, E. Alzahrani, R. Alzahrani, and others, "Teaching and Learning Computer Science at Al Baha University, Saudi Arabia: Insights from a Staff Development Course," in Learning and Teaching in Computing and Engineering (LaTiCE), 2015 International Conference on, 2015, pp. 1-6.

[50] K. Musbah, M. R. Saady, and A. Muhammd, "Comprehensive ELearning System Based on Islamic Principles,” p. 4799, 2013.

[51] A. H. MUHAMMAD and A. SHAH, "CHAPTER FIFTEEN ELEARNING: INCULCATION OF VALUES AND ETHICS IN HIGHER EDUCATION LEARNERS MUHAMMAD SHAHID FAROOQ," Creat. Learn. MOOCs Harnessing Technol. a 21st Century Educ., p. 205, 2015.

[52] K. Nagi, "Solving ethical issues in e-learning," Spec. Issue Int. J. Comput. Internet Manag., vol. 14, no. SP1, pp. 1-7, 2006.

[53] L. M. Hinman, "Academic integrity and the world wide web," ACM SIGCAS Comput. Soc., vol. 32, no. 1, pp. 33-42, 2002. 